\title{
TENT5C wt Allele
}

National Cancer Institute

\section{Source}

National Cancer Institute. TENT5C wt Allele. NCI Thesaurus. Code C96317.

Human TENT 5C wild-type allele is located in the vicinity of $1 \mathrm{p} 12$ and is approximately 22 $\mathrm{kb}$ in length. This allele, which encodes terminal nucleotidyltransferase $5 \mathrm{C}$ protein, plays a role in mRNA polyadenylation. Mutation of the gene may be associated with multiple myeloma. 